\title{
Erythrokeratodermia Variabilis
}

National Cancer Institute

\section{Source}

National Cancer Institute. Erythrokeratodermia Variabilis. NCI Thesaurus. Code C84696.

A rare genetic chronic skin disorder characterized by hyperkeratosis and transient

erythema. Mutations in GJB3 and GJB4 genes have been identified as causative agents. 